Pak. j. sci. ind. res. Ser. A: phys. sci. 2016 59(3) 157-166

\title{
Drinking Water Quality in Urban Areas of Pakistan: A Case Study of Gujranwala City
}

\author{
Sajjad Haydar ${ }^{\mathrm{a}}$, Obaidullah Nadeem ${ }^{\mathrm{b} *}$, Ghulam Hussain ${ }^{\mathrm{a}}$, Haroon Rashid ${ }^{\mathrm{a}}$ \\ and Rashid Majeed ${ }^{\mathrm{a}}$ \\ ${ }^{a}$ Institute of Environmental Engineering \& Research (IEER), University of Engineering \& Technology (UET), \\ Lahore, Pakistan \\ ${ }^{\mathrm{b} C i t y}$ and Regional Planning Department, University of Engineering and Technology, Lahore-54890, Pakistan
}

(received December 8, 2014; revised October 14, 2015; accepted October 15, 2015)

\begin{abstract}
A study was conducted to evaluate the drinking water quality of Gujranwala city. Samples were collected from 16 locations including: 4 tube wells, 4 overhead reservoirs (OHR) and 8 house connections. Twelve physicochemical and two bacteriological parameters were tested, before and after monsoon and compared with National Standards for Drinking Water Quality (NSDWQ). The results demonstrated that most of the physicochemical parameters, except lead, nickle and chromium were within NSDWQ before and after monsoon. Bacteriological and heavy metal contamination was found before and after the monsoon. Possible reasons of contamination are: no disinfection, old and leaking water pipes, poor drainage during monsoon and possible cross connections between water and sewerage lines. It is recommended to practice disinfection, laying of water and sewerage pipes on opposite sides of streets and periodic water quality monitoring.
\end{abstract}

Keywords: water quality, physicochemical characteristics, bacteriological characteristics

\section{Introduction}

Use of contaminated water has its health and financial cost. In terms of health cost, it is reported that $80 \%$ of all diseases in developing countries may be attributed to the use of contaminated water (Leeuwen, 2000). Poor water quality is cause for the death of an estimated 5 million children in developing countries. In terms of financial cost, the UN estimates that $\$ 7.3$ billion may be saved in healthcare costs by improving water quality and sanitation conditions (NDRC, 2014). Rapid increase in population, especially in urban areas has led to poor water quality management which is further aggravating the problem (Huang and Xia, 2001).

Pakistan has existing water supply coverage of $79 \%$ (Aziz, 2009). Due to rapid population growth, annual per capita water supply has been decreased from 5000 cubic meter in 1951 to $1100 \mathrm{~m}^{3}$ in 2011 (WAPDA, 2004). Groundwater is one of the major sources for public water supplies in Pakistan (Tahir et al., 2010).

It is estimated that in Pakistan $30 \%$ of all diseases and $40 \%$ of all deaths are due to poor water quality (Haydar et al., 2009). Diarrhoea, a water borne disease is reported as the leading cause of death in infants and children in the country while, every fifth citizen suffers from illness *Author for correspondence; E-mail: obaidnadeem@uet.edu.pk and disease caused by the polluted water (Kahlown et al., 2006). Unfortunately, little attention is being paid to drinkingwater quality issues and quantity remains the main concern of water supply agencies. There is a lack of drinkingwater quality monitoring and surveillance programmes in the country. Weak institutional arrangements, lack of well-equipped laboratories and poor implementation of NSDWQ have aggravated the situation. In particular, the public awareness of the issue of water quality is dismally low (Aziz, 2005).

Various studies have been carried out on water quality of Pakistan (Haydar and Qasim, 2013; Khan et al., 2013; Ali et al., 2012; Kausar et al., 2011; Tahir et al., 2010; Haydar et al., 2009; Aziz, 2005; Kazmi, 2004). It is concluded that drinking water quality in both urban and rural areas of Pakistan is not being managed properly. At some places groundwater quality is deteriorating due to the naturally occurring subsoil contaminants or due to anthropogenic activities. Improper disposal of sewage and solid wastes, over application of agrochemicals (pesticides and fertilizers) and deteriorating condition of piping network are the major responsible sources for contamination of water supplies. Microbiological contamination is the main source of waterborne diseases like gastroenteritis, dysentery, diarrhoea and viral hepatitis. 
Outbreaks of gastroenteritis and other waterborne diseases have become a normal aspect in Pakistan (Bridges, 2007). Estimates signify that more than three million Pakistanis suffer from waterborne diseases each year of which 0.1 million die (World Bank, 2005). Thus there is a need to find out where the actual problem lies; whether the water sources are contaminated or lapses occur in the distribution system. This research work was undertaken with the objectives of: (1) Detailed evaluation of drinking water quality of Gujranwala City. (2) Suggestions and recommendations for improvement of the situation so that sanitation and health problems may be minimized.

\section{Materials and Methods}

Sampling area. Gujranwala city was selected for this study. Gujranwala is the $5^{\text {th }}$ largest city in Pakistan. The main water source is groundwater, which is drawn by installing tube wells (TWs). The water is at a depth of $55 \mathrm{ft}$ and depths of TWs vary from 450 to $650 \mathrm{ft}$. Four localities of Gujranwala municipality were sampled for the purpose of this study (Fig. 1). The localities included: Model Town, Sharanwala Bagh, Satellite Town and Peoples Colony. Water and Sanitation Agency (WASA) is responsible for provision of water and sanitation services to the city.

One water source i.e. TW was selected in each locality. According to WHO Guidelines, one sample per 5000

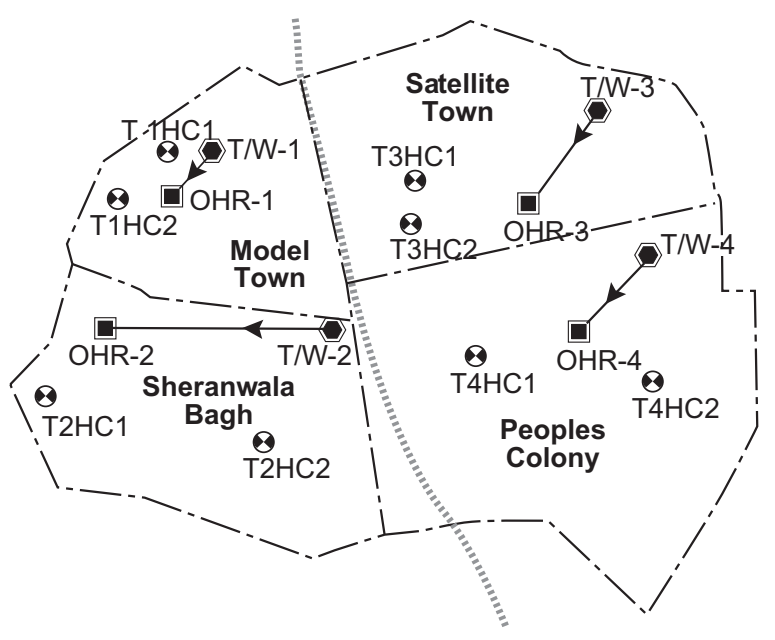

Tube well (T/W) $\square$ Overhead reservoir (OHR)

(3) House connection (HC)

Fig. 1. Location plan of sampling points. heads of population should be collected from the distribution system (WHO, 2004). Since all these localities have a population ranging from 6000 to 9000 , therefore, two samples from the distribution system of each TW were collected. Water samples from distribution system were taken at points located at the farthest distance from the TW to evaluate the effect of distribution network on the quality of water. The complete detail and nomenclature used for the sampling locations are given in Table 1.

Sampling methodology. From each sampling location, samples were collected before and after the monsoon as recommended in WHO Guidelines (WHO, 2011). For statistical significance of the test results, each sampling location was sampled three times before and three times after the monsoon on the dates as shown in Table 2. On a specific date, samples from all the sixteen sampling locations were collected. In this way, a total of 96 samples were collected and tested during this study. Values reported for each sampling point, are the mean of three samples.

Table 1. Description of the sampling points

\begin{tabular}{ll}
\hline \hline $\begin{array}{l}\text { Sampling } \\
\text { points }\end{array}$ & Description \\
\hline TW1 & Tube well installed for main city area at Model Town \\
OHR-1 & Over Head Reservoir for main city area at Model Town \\
TW1HC1 & House connection no.1 of TW1 \\
TW1HC2 & House connection no. 2 of TW1 \\
TW2 & Tube well installed for main city area at Sharanwala Bagh \\
OHR-2 & Over Head Reservoir for main city area at Sharanwala Bagh \\
TW2HC1 & House connection no. 1 of TW2 \\
TW2HC2 & House connection no. 2 of TW2 \\
TW3 & Tube well installed for main city area at Satellite Town \\
OHR-3 & Over Head Reservoir for main city area at Satellite Town \\
TW3HC1 & House connection no. 1 of TW3 \\
TW3HC2 & House connection no. 2 of TW3 \\
TW4 & Tube well installed for main city area at Peoples Colony \\
OHR-4 & Over Head Reservoir for main city area at Peoples Colony \\
TW4HC1 & House connection no. 1 of TW4 \\
TW4HC2 & House connection no. 2 of TW4 \\
\hline
\end{tabular}

Table 2. Sampling schedule

\begin{tabular}{|c|c|c|c|c|c|c|}
\hline \multirow[b]{2}{*}{ Sample no. } & \multicolumn{3}{|c|}{ Before monsoon } & \multicolumn{3}{|c|}{ After monsoon } \\
\hline & 1 & 2 & 3 & 1 & 2 & 3 \\
\hline $\begin{array}{l}\text { Sampling } \\
\text { date (2011) }\end{array}$ & May 12 & May 27 & Jun. 11 & Aug. 11 & Aug. 26 & Sep. \\
\hline
\end{tabular}


For physicochemical analysis, water samples were collected in a $1 \mathrm{~L}$ polyethylene (PET) bottle while a $0.5 \mathrm{~L}$ sterilized PET bottle was used to collect sample for bacteriological analysis. In case of water samples from the distribution system, un-rusted taps were selected. Samples were not taken from those taps which were leaking between the spindle and gland to avoid outside contamination. Taps were opened fully and let to run for 2 to $3 \mathrm{~min}$ before sampling to get a truly representative sample both from the source and the distribution system. The samples were transported to the lab within 2 h. All tests, except heavy metals were conducted on the same day. For heavy metals, filtration and acidification/digestion of samples were done and stored at $4{ }^{\circ} \mathrm{C}$. Atomic Adsorption Spectro-photometer, Perkin Elmer AAnalyst 800 was used for measuring the concentrations of heavy metals in the samples.

Parameters tested. Fourteen water quality parameters (twelve physicochemical and two microbiological) were tested for each water sample. The parameters and testing procedure used have been listed in Table 3 .

These parameters were selected on the basis of Section 4.2.2 of WHO Guidelines (WHO, 2004). All the tests were conducted according to the procedures laid down in the Standard Methods (APHA, 1998). Measured values were compared with NSDWQ and where no value in NSDWQ was provided WHO Guidelines for drinking water were used for comparison (WHO, 2011).

Table 3. Parameters tested for sampled water

\begin{tabular}{ll}
\hline \hline Parameters & Testing methods \\
\hline Physiochemical & \\
$\mathrm{pH}$ & $4500-\mathrm{H}^{+} \mathrm{B}$ \\
Turbidity & $2130 \mathrm{~B}$ \\
Hardness & $2340 \mathrm{C}$ \\
Total dissolved solids (TDS) & $2540 \mathrm{C}$ \\
Calcium & $3500-\mathrm{Ca} \mathrm{B}$ \\
Magnesium & $3500-\mathrm{Mg} \mathrm{B}^{2-}$ \\
Sulphate & $3500-\mathrm{SO}_{4}{ }^{-} \mathrm{E}$ \\
Chloride & $4500-\mathrm{Cl}-\mathrm{C}$ \\
Arsenic & $3500-\mathrm{As} \mathrm{B}$ \\
Lead & $3500-\mathrm{Pb} \mathrm{B}$ \\
Nickel & $3500-\mathrm{Ni} \mathrm{B}$ \\
Chromium & $3500-\mathrm{Cr} \mathrm{B}$ \\
Bacteriological & \\
Total coliform (TC) & $9221 \mathrm{C}$ \\
Fecal coliform (FC) & $9221 \mathrm{C}$ \\
\hline \hline
\end{tabular}

\section{Results and Discussion}

Physicochemical parameters. $\boldsymbol{p H}$. The values of $\mathrm{pH}$ at 16 sampling points before and after the monsoon are shown in Fig. 2. Health based guidelines have not been proposed by WHO for the $\mathrm{pH}$ of drinking water (WHO, 2004), however, it is one of the most important operational water quality parameters. $\mathrm{pH}$ values higher than 8 are not suitable for effective disinfection while values less than 6.5 enhance corrosion in water mains and household plumbing system (WHO, 2004). Therefore, National Standards for Drinking Water Quality (NSDWQ) proposes a desirable range of 6.5 to 8.5 for $\mathrm{pH}$ of drinking water (NSDWQ, 2010). It can be seen in Fig. 2 that $\mathrm{pH}$ values at most of the TWs, OHRs and house connections were within the NSDWQ desirable limit both, before and after the monsoon season.

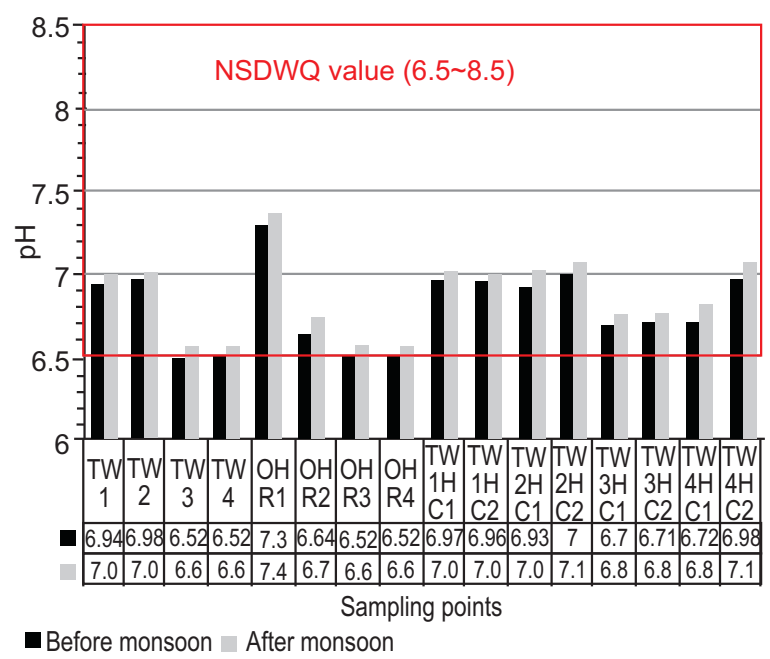

Fig. 2. Mean values of $\mathrm{pH}$ at various sampling points before and after monsoon.

Turbidity. Mean values of turbidity at all the sampling locations before and after the monsoon have been shown in Fig. 3. A value of 0.5 NTU is recommended for effective disinfection (WHO, 2011). On the other hand, a value upto $5 \mathrm{NTU}$ is considered acceptable to the consumers (NSDWQ, 2010). It is evident from Fig. 3 that values of turbidity at all the sampling locations were below 5 NTU. Values of turbidity rose in water samples obtained from all the locations after the monsoon. This difference was however, very small. No apparent reason could be ascribed to this phenomenon on the basis of this study. 


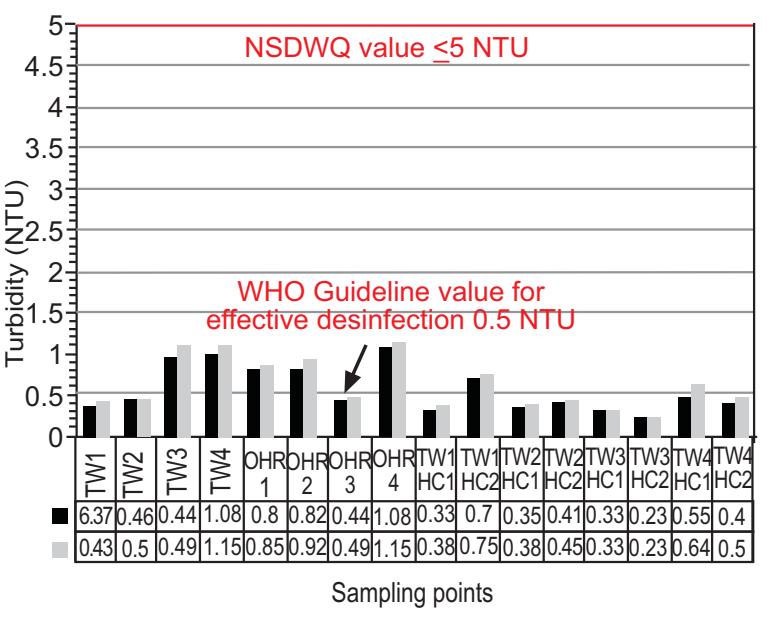

- Before monsoon $\square$ After monsoon

Fig. 3. Mean values of turbidity at various sampling points before and after monsoon.

Total dissolved solids. The mean values of total dissolved solid (TDS) in samples are presented in Fig. 4. No health based guideline is proposed by WHO for TDS. Since TDS higher than $1000 \mathrm{mg} / \mathrm{L}$ impart taste to the water, therefore, a desirable value of $1000 \mathrm{mg} / \mathrm{L}$ is proposed by NSDWQ. Furthermore, a value higher than $1000 \mathrm{mg} / \mathrm{L}$ results in excessive scales in water pipes, heaters, boilers and household appliances (WHO, 2004).

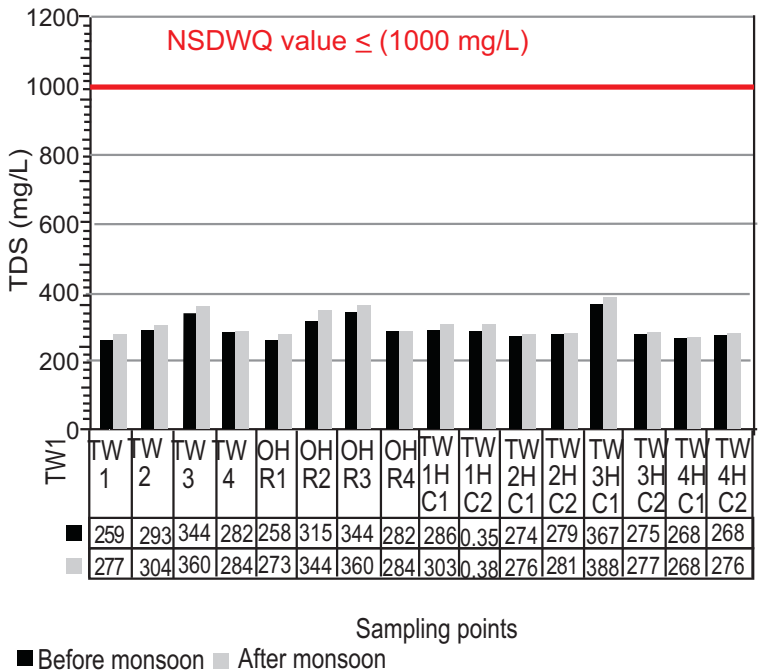

Fig. 4. Mean values of total dissolved solids (TDS) at various sampling points before and after monsoon.
Figure 4 shows that TDS values at the sources: TWs, OHRs and HCs were well below the desirable value of $1000 \mathrm{mg} / \mathrm{L}$. It can further be pointed out that TDS in the collected samples slightly increased at some sampling points after monsoon.

Calcium. The mean calcium values for samples are presented in Fig. 5. No health based guideline is proposed by WHO for calcium. Calcium is a mineral needed for several body functions, including the transmission of nerve impulses, blood clotting and the regulation of the heart's rhythm. People who drink water lacking in calcium are vulnerable to mortality from cardiovascular disease (Musa et al., 1999).

It can be seen in Fig. 5 that calcium values at the sampling points TW, OHR and HCs were below the upper limit of $200 \mathrm{mg} / \mathrm{L}$. It can further be pointed out that calcium in the collected samples slightly increased at some sampling points after monsoon. Changes may be due to the mixing by interconnected water supply system of the city.

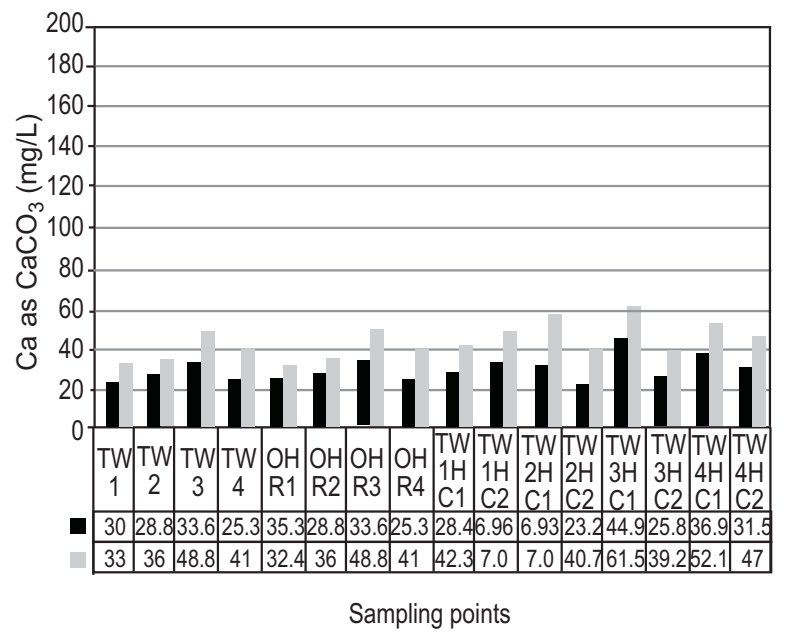

Before monsoon $\square$ After monsoon

Fig. 5. Mean values of calcium as $\mathrm{CaCO}_{3}$ at various sampling points before and after monsoon.

Magnesium. The mean values of magnesium in the samples are presented in Fig. 6. No health based guideline is proposed by WHO for magnesium. Magnesium is important for bone health and cardiovascular diseases. It can be seen in Fig. 6 that magnesium values, at the sources TWs, OHRs and HCs were below $150 \mathrm{mg} / \mathrm{L}$. 
It can further be pointed out that magnesium in the collected samples was slightly increased at some sampling points after monsoon.

Sulphate. The mean values of sulphate in the water samples have been shown in Fig. 7. It can be seen that sulphates at all the sources i.e. TWs, OHRs and HCs were below $250 \mathrm{mg} / \mathrm{L}$. Higher values may contribute to distribution systems corrosion and cause noticeable taste. Low to moderate concentrations of sulphate ions add palatability to water (WHO, 2004). Sulphate for

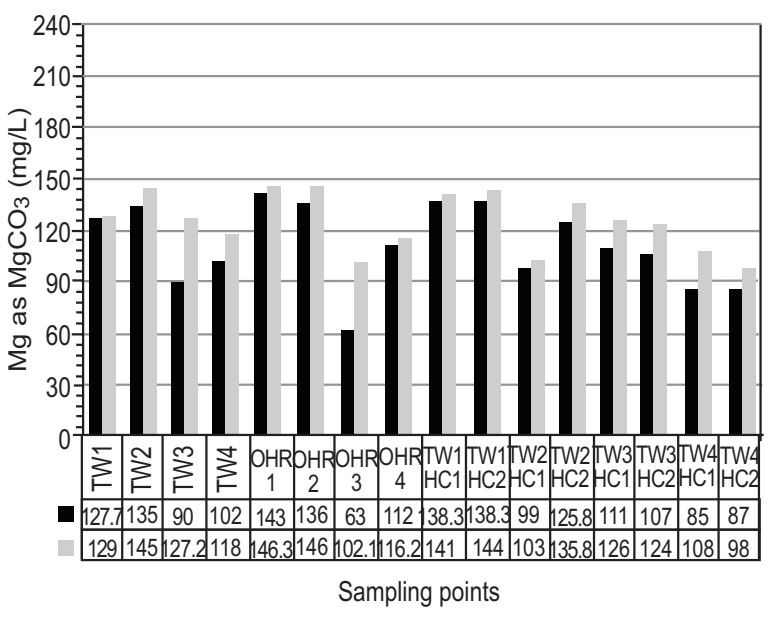

-Before monsoon $\square$ After monsoon

Fig. 6. Mean values of magnesium as $\mathrm{MgCO}_{3}$ at various sampling points before and after monsoon.

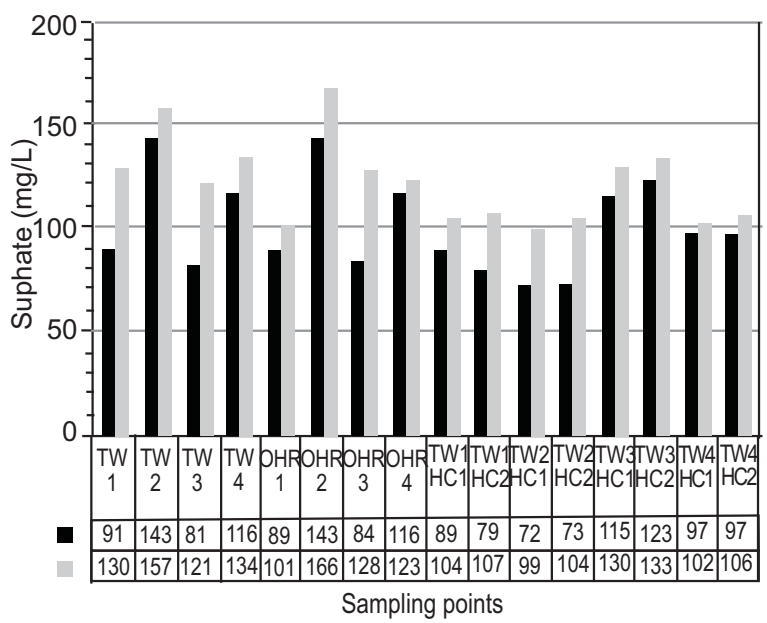

घefore monsoon $\square$ After monsoon

Fig. 7. Mean values of sulphate at various sampling points before and after monsoon. sources TW varied from 81.4 to 156.5 , for OHRs from 84 to 166.4 and for HCs from 72 to $133.7 \mathrm{mg} / \mathrm{L}$ before and after the monsoon. It was noted that an increase in sulphate for all sources, OHRs and HCs was observed after monsoon. It may be due to seepage of additional salts after monsoon.

If the sulphate values at sources TWs, OHRs and respective HCs are compared then it is revealed that the sulphate at house connections sometimes increased as compared to the sulphate at the source (TW3, TW3HC1 and TW3HC2). It may be due to interconnected water supply system of WASA which bring variations.

Chloride. The mean values of chloride in samples are presented in Fig. 8. The chloride may result in noticeable taste at $250 \mathrm{mg} / \mathrm{L}$ but no health-based guideline value is proposed by WHO. Chloride is important in bone health and cardiovascular diseases (WHO, 2004). A desirable value of less than $250 \mathrm{mg} / \mathrm{L}$ is proposed by NSDWQ. A high chloride content has an adverse effect on metallic pipes and structures, besides on vegetation (Kahlown et al., 2006).

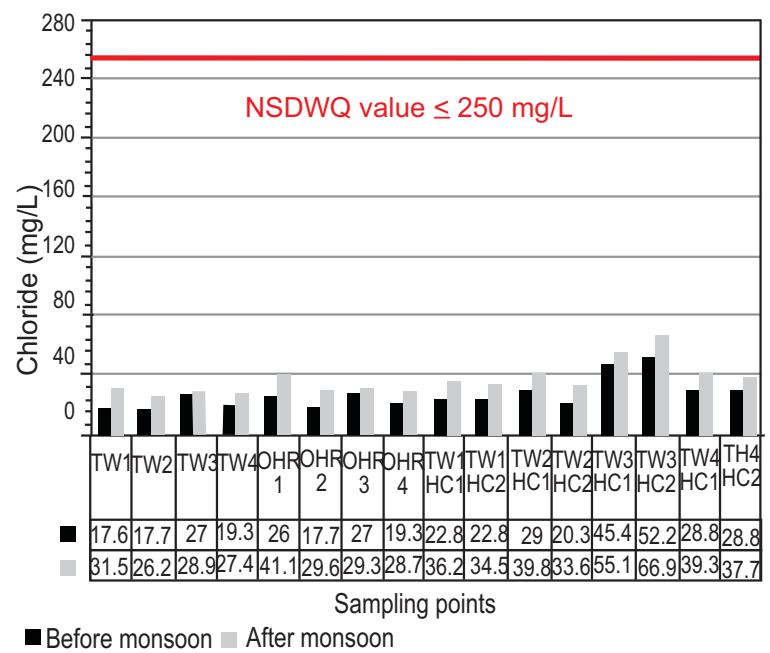

Fig. 8. Mean values of chloride at various sampling points before and after monsoon.

It can be seen in Fig. 8 that chloride values at the sources TWs, OHRs and HCs were well below the desirable value of $250 \mathrm{mg} / \mathrm{L}$. It can further be pointed out that chloride in the collected samples slightly increased in all sampling points after monsoon.

Bacteriological parameters. Total coliform (TC). The mean values of TC for all water samples are presented 
in Fig. 9. TC group includes both faecal and environmental species. Their presence shows that water has come in contact with any of the materials like human faeces, soil, plants etc. (Steel, 1960). It can be seen in Fig. 9 that upon comparing with NSDWQ (0 MPN/100 mL), TC values for samples from all sources before and after monsoon were unsatisfactory. Also TC contamination at all sources increased after monsoon. Similarly, values of TC for OHR-2 and three house connections TW1HC2, TW2HC1 and TW2HC2 were very high, which clearly shows that water distribution system in that area is not in good condition and may contain leakages. Rest of the house connections, in addition to that mentioned above had TC contamination, both before and after the monsoon. In other words, $90 \%$ of house connections were contaminated with TC before monsoon and the percentage rose to $100 \%$ after the monsoon. Test results of source samples of TW ranged from 1.8 to $152 \mathrm{MPN} /$ $100 \mathrm{~mL}$; of OHR ranged from 1.8 to $1600 \mathrm{MPN} / 100 \mathrm{~mL}$ and for HCs ranged from 1.8 to $1600 \mathrm{MPN} / 100 \mathrm{~mL}$.

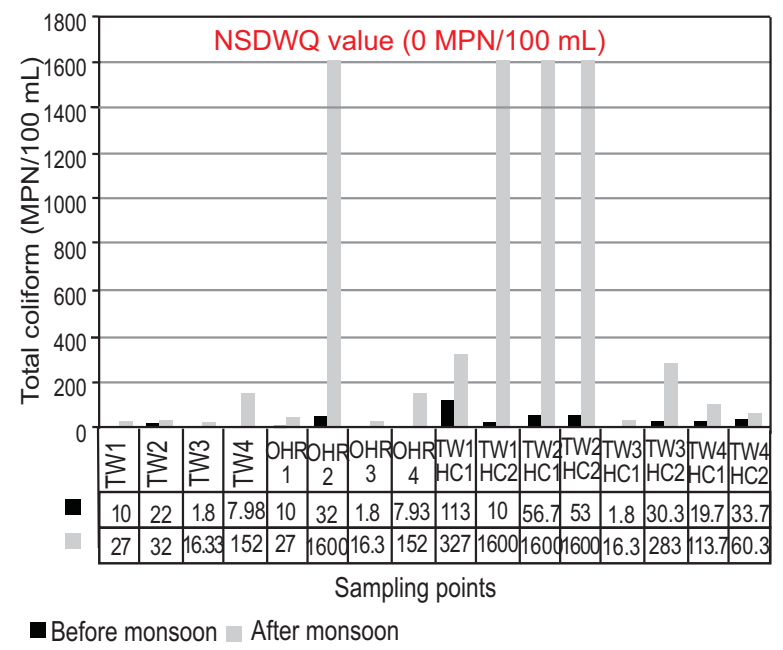

Fig. 9. Mean values of total coliform (TC) at various sampling points before and after monsoon.

At source TW1, TC may be due to pondage near TW1 that may seep due to poor sanitary seal of TWl. As a result of seepage ground water source is also contaminated. At OHRs, it may be due to unsanitary conditions at OHR due to lack of regular cleaning and disinfection. Various reasons of bacteriological contamination at HCs may be: (1) intermittent water supply which allows entry of nearby stagnant water/wastewater in the distribution system through poor joints during no flow conditions, (2) layout of water pipes in close proximity to the sewer lines and (3) overloading of sewage channels and sewers which in most cases remain blocked. The sampling site TW1HC2 had stagnant rain water in front of house connection due to blockage of sewer line. Water sample from this house connection had TC before and after the monsoon.

Faecal coliform (FC). Mean values of FC at various sampling locations are shown in Fig. 10. Faecal contamination shows that water has come in contact with human faeces. It is evident from Fig. 10 that all the sources (TW) are not free from FC, both before and after the monsoon except TW4 and OHR4 that were free from $\mathrm{FC}$ before the monsoon. It shows that FC were not present before the monsoon and only appeared after it. Rest of the house connections, in addition to those mentioned above were faecally contaminated before and after the monsoon. In other words, $80 \%$ of the house connections were faecally contaminated before the monsoon and this percentage rose to $90 \%$ after the monsoon. Test results of source samples of TW ranged from 0 to $26 \mathrm{MPN} / 100 \mathrm{~mL}$ : whereas, of OHR ranged from 0 to $124 \mathrm{MPN} / 100 \mathrm{~mL}$ and of house connections ranged from 3 and $134 \mathrm{MPN} / 100 \mathrm{~mL}$. Upon comparing with NSDWQ (0 MPN/ $100 \mathrm{~mL}$ ), FC values for samples from all sources before and after monsoon were not fit for human consumption. Also FC contamination slightly increased at all sources, after monsoon.

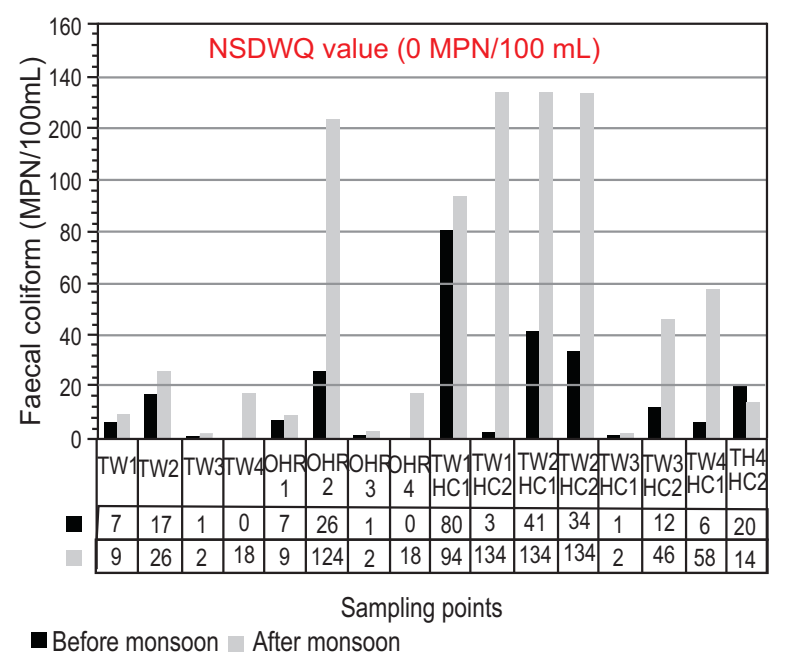

Fig. 10. Mean values of faecal coliform at various sampling points before and after monsoon. 
At source TW, FC contamination may be due to poor sanitary seal of TW. In most of the cases where bacteriological contamination was found, it was observed that ponding of wastewater from blocked pipes or stagnation of rain water due to improper drainage could be a reason. Under such conditions, poor sanitary seal is unable to prevent the seepage of ponded water into the tube wells.

Pipe material used in the study area was galvanized iron and asbestos cement and was 30-35 years old. Water supply and sewer lines in some areas were laid in one trench, side by side, without any consideration of safe distance between both lines. Thus very high values may be due to cross connection between sewer lines and water supply lines. Another reason may also be the use of donkey pumps by consumers. The suction created could have sucked in the outside stagnant rain/ wastewater. Thus leaking water lines, intermittent water supply, and poor maintenance of water distribution system may be the cause of bacteriological contamination. Although, all the TWs were equipped with chlorination devices but none was functional or in regular use. The water supply operating agency has no monitoring programmes to evaluate the water quality on regular basis.

Heavy metals. Arsenic. The mean values of arsenic in the water samples at all the locations have been shown in Fig. 11. It can be seen in the figure that arsenic at all the points i.e. TWs, OHRs and HCs meet NSDWQ i.e. $50 \mathrm{ppb}$. However, WHO prescribed an upper limit of

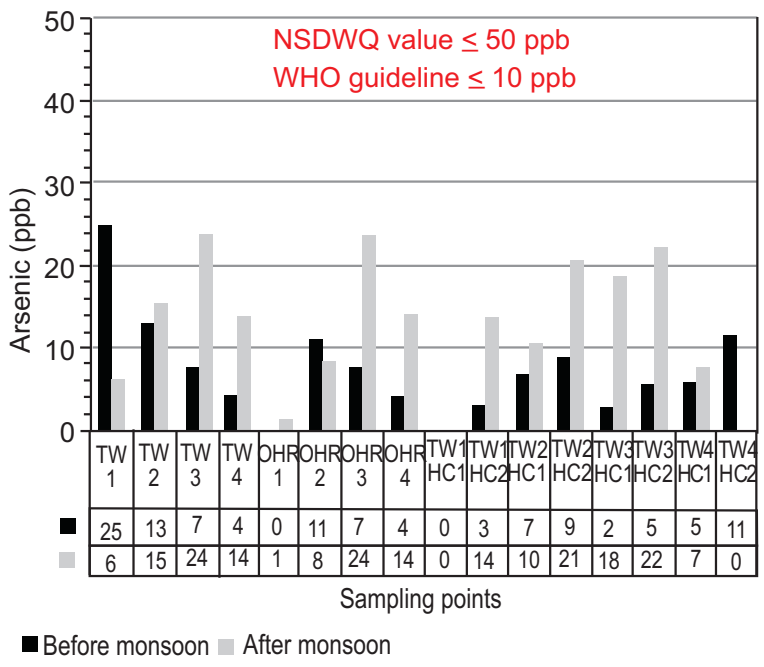

Fig. 11. Mean values of arsenic at various sampling points before and after monsoon.
$10 \mathrm{ppb}$. Arsenic has no smell or taste and hence can only be detected if tested in the laboratory. Mineral deposits in some areas naturally contain high levels of arsenic. Groundwater flowing through these deposits can dissolve arsenic from the minerals.

Arsenic is introduced into underground drinking water sources primarily through the dissolution of naturally occurring minerals and ores. Intake of great quantities through drinking water is health hazard to human kidney, lungs, hair, liver, skin and even causes cancer (USEPA, 2013). Arsenic for sources (TW) varied from 3.79 to $25 \mathrm{ppb}$. Upon comparing with NSDWQ (50 ppb), all the source samples were satisfactory before and after monsoon. For OHRs the variation was 0 to $24 \mathrm{ppb}$ which is also less than NSDWQ. Therefore, water quality of all OHR's was also satisfactory. The value of arsenic for samples obtained from house connections ranged from 0 to $22 \mathrm{ppb}$, which was within the range prescribed by NSDWQ. If the arsenic values at sources TWs, OHRs and respective HCs are compared then it is revealed that the arsenic at house connections sometimes increased as compared to the arsenic at the source (TW3 and TW3HC3). It might be due to the reason that while travelling from source to the house connection, the water pass through rusted pipes. When samples from HCs were acidified, these rust might have released arsenic.

Lead. The mean values of lead in samples taken at all the locations are presented in Fig. 12. Lead can accumulate in human body over some time and causes serious damage to kidney, brain, nerveus and red blood cells. For infants, large amount of lead can cause delays in physical and mental development. Most lead in drinking water comes from lead lined pipes, lead solder and brass plumbing fixtures inside the houses. Usually lead in drinking water originated between the water main in the street and the household faucet. The USEPA estimates that $98 \%$ of all homes have pipes, fixtures or solder joints in the household plumbing that can contribute some level of lead to the tap water (USEPA, 2013). The quantity of lead dissolved from the plumbing system depends on a number of factors, including temperature, $\mathrm{pH}$, water hardness and standing time of the water, with soft, acidic water being the most plumbosolvent (WHO, 2004).

It was found that the lead results of source samples ranged from to 0.24 to $3.99 \mathrm{mg} / \mathrm{L}$. Upon comparing with NSDWQ (0.05 mg/L), lead values for samples 


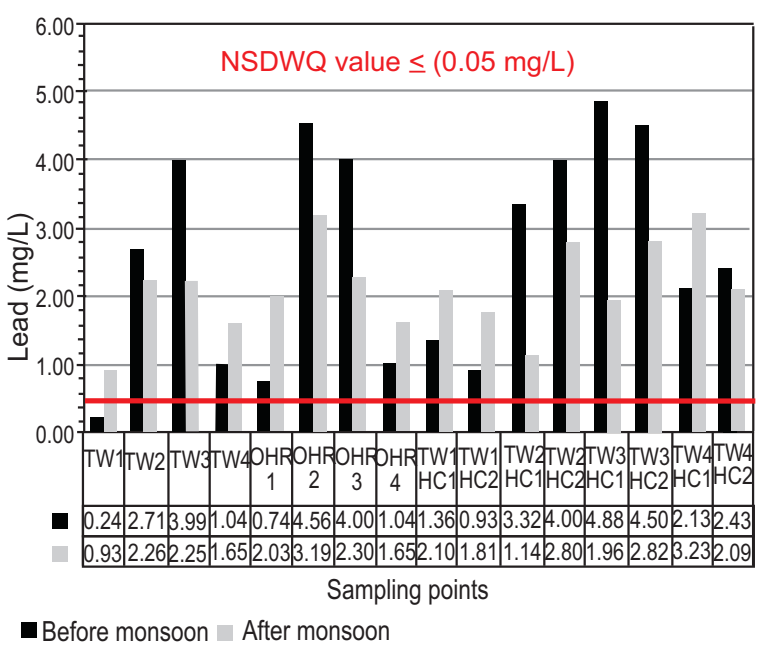

Fig. 12. Mean values of lead at various sampling points before and after monsoon.

from all sources before and after monsoon were unsatisfactory with respect to NSDWQ. Test results of OHRs ranged from 0.74 to $4.56 \mathrm{mg} / \mathrm{L}$. Lead values at all the OHR samples did not satisfy NSDWQ. Test results of HCs ranged from 0.93 to $4.88 \mathrm{mg} / \mathrm{L}$. lead values at all HCs were not within the limits prescribed by NSDWQ (2010).

Probable reason of lead contamination may be anthropogenic i.e., due to large scale industrial activities and failure to treat industrial wastewater before its disposal into the WASA sewerage system, which in turn leads to groundwater contamination through seepage.

Nickel. The mean values of nickel in the water samples are shown in Fig. 13. It can be seen that nickel at all the points was higher than the limits prescribed by NSDWQ value i.e., $0.02 \mathrm{mg} / \mathrm{L}$. Nickel is a metal typically used to manufacture alloys and stainless steel. Nickel released from taps and fittings may contribute up to 1 $\mathrm{mg} / \mathrm{L}$ concentration (WHO, 2004). Nickel for sources TWs varied from 0.02 to $2.01 \mathrm{mg} / \mathrm{L}$. Upon comparing with NSDWQ $(0.02 \mathrm{mg} / \mathrm{L})$, all the source samples were unsatisfactory before and after monsoon but source TW3 was satisfactory before monsoon. The value for OHRs lied in a range of $0.02-2.01 \mathrm{mg} / \mathrm{L}$. The value of nickel for samples obtained from HCs ranged from $<0.01$ to $1.25 \mathrm{mg} / \mathrm{L}$. Nickel values for samples from all HCs before and after monsoon were unsatisfactory with respect to NSDWQ but T3HC1, T3HC2 and T4HC1 were satisfactory before monsoon.

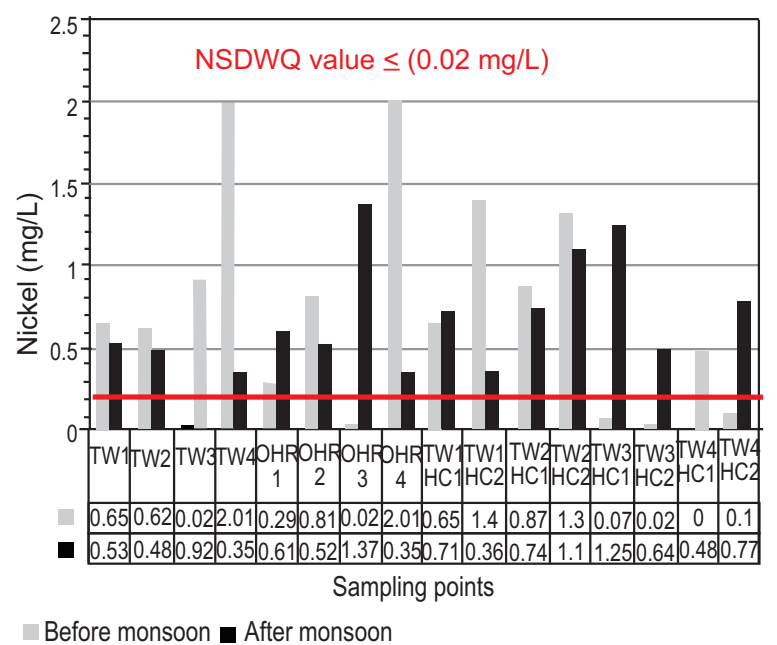

Fig. 13. Mean values of nickel at various sampling points before and after monsoon.

If the Nickel values at sources TWs, OHRs and respective HCs are compared then it is revealed that the nickel at house connections varies as compared to the nickel at the source (TW2 and TW2HC2). It may be due to interconnected water supply system of WASA.

Chromium. The mean values of chromium are presented in Fig. 14. It makes compounds of potassium dichromate $\left(\mathrm{K}_{2} \mathrm{Cr}_{2} \mathrm{O}_{7}\right)$ and chromic acid after dissolving in water. Chromium is used as oxidizing reagent for dyeing, leather processing, electroplating and in textile industry. Chromium may be accumulated in liver and kidneys (WHO, 2004).

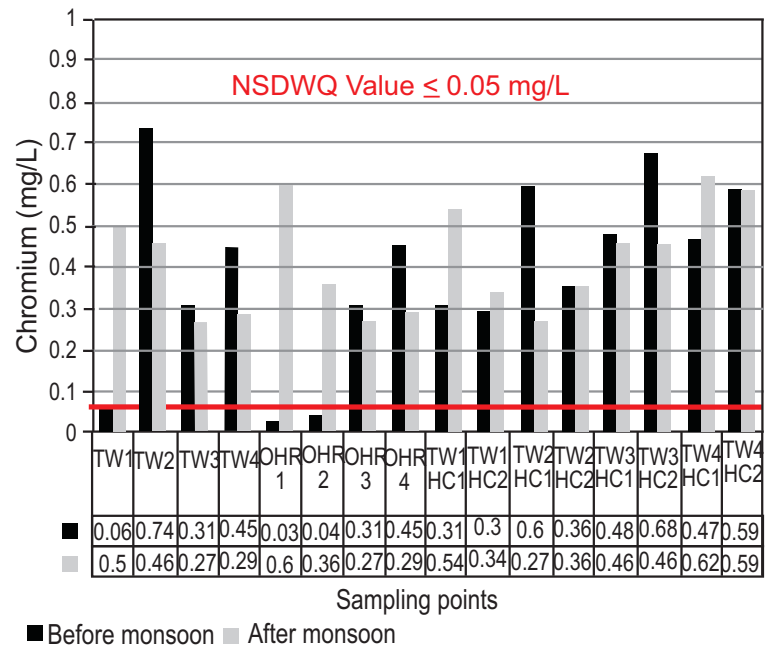

Fig. 14. Mean values of chromium at various sampling points before and after monsoon. 
It was found that chromium concentration ranged from 0.06 to $0.74 \mathrm{mg} / \mathrm{L}$ at TWs, which is more than the limit given in NSDWQ $(0.05 \mathrm{mg} / \mathrm{L})$. Test results of OHRs ranged from 0.03 to $0.45 \mathrm{mg} / \mathrm{L}$. For house connections, chromium concentration ranged from 0.27 to $0.68 \mathrm{mg} / \mathrm{L}$.

It can be seen in Fig. 14 that chromium values, at the sources TWs, OHRs and HCs were above the NSDWQ limit. The possible reason may be disposal of untreated industrial wastewater into Upper Chenab Canal. This canal is unlined and seepage water recharge the groundwater. Further investigation is needed to ascertain the above proposition by determining the direction of groundwater flow and quality of the canal water.

\section{Conclusion}

Samples from TWs, OHRs and HCs are satisfactory with respect to physicochemical characteristics before and after the monsoon. Water is not fit for drinking due to bacteriological contamination, which rose from 80 to $100 \%$ of the sampled water before and after the monsoon, respectively. Chromium, lead and nickel were high which needs immediate attention of WASA Gujranwala. WASA is paying little attention to water quality monitoring plans and surveillance programmes for improvement of the situation.

To limit bacteriological contamination, water should be disinfected at source (TW). It is recommended to carry out compulsory chlorination at water sources while maintaining sufficient residual chlorine at the consumers' end to eliminate the bacteriological contamination. All the chlorinators may be made functional. In areas like main city, Sharanwala Bagh and Model Town, old, rusted and leaked water lines should be repaired. In Satellite Town and Sharanwala Bagh, new water and sewer lines should be re-laid on opposite sides of the roads. Ponding of rain/wastewater in the streets be avoided through better drainage system. Public be made aware of significance of water related issues. Print and electronic media can play key role in this regard.

\section{Acknowledgement}

This is to acknowledge University of Engineering and Technology, Lahore, Pakistan for providing funds to carryout this research study by head grant 22000 . The assistance of Mr. Muhammad Shabbir in laboratory work is also acknowledged.

\section{References}

Ali, S., Hussain, A., Hussain, A., Ali, A., Awan, M.S. 2012. Drinking water quality assessment in some selected villages of Nagar Valley Gilgit-Baltistan, Pakistan. Journal of Chemical, Biological and Physical Sciences, 3: 567-574.

APHA, 1998. Standard Methods for the Examination of Water and Wastewater. $20^{\text {th }}$ edition, American Public Health Association, American Water Works Association, Water Environment Federation, USA.

Aziz, J.A. 2009. Drinking water quality in Punjab. In: Proceedings of Pakistan Engineering Congress, Lahore. Retrieved April, 14, 2014 from http://www. pecongress.org.pk/images/upload/books/616.pdf.

Aziz, J.A. 2005. Management of source and drinkingwater quality in Pakistan. Eastern Mediterranean Health Journal, 11: 1087-1098.

Bridges, G. 2007. Asian Water Development Outlook. 18 pp., Country Paper Pakistan. Asian Development Bank, Islamabad. Retrieved March 20, 2014 from http://waterinfo.net.pk/sites/default/knowledge/A WDO\%202007\%20-\%20Pakistan20Country\% 20Paper.pds.

Haydar, S., Qasim, M. 2013. A study of water quality of Sargodha City. Pakistan Journal of Engineering \& Applied Sciences, 13: 110-117.

Haydar, S., Aziz, J. A., Arshad, M. 2009. Evaluation of drinking water quality in urban areas of Pakistan: A case study of southern Lahore. Pakistan Journal of Engineering \& Applied Sciences, 5: 16-23.

Huang, G. H., Xia, J. 2001. Barriers to sustainable water-quality management. Journal of Environmental Management, 61: 1-23.

Kahlown, M.A., Tahir, M.A., Rasheed, H., Bhatti, K.P. 2006. Water Quality Status. National Water Quality Monitoring Programme, Fourth Technical Report. pp. 6, 26, Pakistan Council of Research in Water Resources, Islamabad, Pakistan.

Kausar, S., Asghar, K., Anwar, S.M., Shaukat, F., Kausar, R. 2011. Factors affecting drinking water quality and human health at household level in Punjab, Pakistan. Pakistan Journal of Life \& Social Science, 9: 33-37.

Kazmi, S. 2004. A Prospective Study of Local Drinking Water Quality and its Impact on Health. Ph.D. Thesis, Department of Biological Sciences, Quaid-i-Azam University, Islamabad, Pakistan.

Khan, S., Shahnaz, M., Jehana, N., Rehmana, S., Shahc, M.T., Dind, I. 2013. Drinking water quality and 
human health risk in Charsadda district, Pakistan. Journal of Cleaner Production, 60: 93-101.

Leeuwen, F.X.R. Van. 2000. Safe drinking water: The toxicologist's approach. Food and Chemical Toxicology, 38: $51-58$.

Musa, H.A., Shears, P., Kafi, S., Elsabag, S.K. 1999. Water quality and public health in northern Sudan: A study of rural and peri-urban communities. Journal of Applied Microbiology, 87: 676-682.

NDRC, 2014. Safe water: Keystone of environment, health, economy and security. Retrieved October 30, from http://www.nrdc.org/international/safewater.asp.

NSDWQ, 2010. National Standards for Drinking Water Quality. pp. 3207-3209, Ministry of Environment, Government of Pakistan, Islamabad. Notification No. S.R.O. 1063(I).

Steel, W.E. 1960. Water Supply and Sewerage. 209 pp., $4^{\text {th }}$ edition. Mc-Graw Hill Book Company, New York, USA.

Tahir, M.A., Rasheed, H., Imran, S. 2010. Water Quality Status in Rural Areas of Pakistan. 3 pp., Pakistan Council of Research in Water Resources (PCRWR),
Islamabad, Pakistan.

USEPA, 2013. Drinking Water Standard. United States Environment Protection Agency, USA. Retrieved July 112014 from http://water.epa.gov/drink/ standardsriskmanagement.cfm.

WAPDA, 2004. Water Availability vs Population Growth. 1 pp., Water and Power Development Authority, Government of Pakistan, Islamabad. Retrieved June 5, 2014 from http://www.wapda. gov.pk/pdf/ kbdam.pdf.

WHO, 2011. Guidelines for Drinking Water Quality. vol. 1, 229 pp. $4^{\text {th }}$ edition, World Health Organization, Geneva, Switzerland.

WHO, 2004. Guidelines for Drinking Water Quality. vol. 1, $3^{\text {rd }}$ edition, World Health Organization, Geneva, Switzerland.

World Bank, 2005. Managing Karachi's Water Supply and Sanitation Services: Lessons from a Workshop. World Bank, Karachi. Retrieved March 20, 2014 from.http:/wwe-wds.worldbank.org/external/ default/WDSContentServer/WDSP/IB/2005/11/2 8/000160016_20051128162902/Rendered/PDF/3 44430PK0Karachi0water0supply.pdf. 